\title{
Territory of Agon. Civilian Perspective in a Besieged City in the Computer Game This War of Mine
}

\author{
Kamila Gieba \\ Doctor of Science (Literary Studies), University of Zielona Góra \\ (Zielona Góra, Poland) \\ E-mail:k.gieba@gmail.com \\ https://orcid.org/0000-0002-6671-7413
}

In 2014, the Polish studio 11 Bits Studio produced the computer game entitled This War of Mine. The concept of this game was based on the course of the siege of Sarajevo. This production has changed the way of representation of war in video games. The main characters are not soldiers, but civilians, whose main aim is: to simply survive the war. Starvation, cold, lack of sleep and psychosomatic problems turn out to be more dangerous than the enemy's army. Survival is possible, but forces the player to make ethically ambiguous decisions. The aim of the paper is to determine how the creators of the game presented the perspective of the civilians. This analysis will be based on the plot and mechanics of This War of Mine, on the historical context (war in the Balkans: the siege of Sarajevo) and with regard to virtual war schemes (topic of war in video games). The paper will also propose a concept of the game about war as an agon: the territory of not only a conflict, but also competition and a war spectacle.

Keywords: computer games, war, Sarajevo, representation

Received: October 16, 2019; accepted: October 25, 2019

Future Human Image, Volume 12, 2019: 22-27.

https://doi.org/10.29202/fhi/12/2

\section{Introduction}

In 2014, the Polish studio 11 Bit Studios released the computer game This War of Mine, which differs from previous games that represent wars in video games: it differs from construction of earlier war games in terms of elements such as construction of the plot and heroes, and the purpose of the game. This case study aims to show what changes in the virtual representation of wars took place in This War of Mine. First of all, point to the feature outline and characteristic elements of the game related to the mechanics of operation in the virtual world of the game. Next, I will briefly refer to the real conflict that inspired its creators, which is the siege of Sarajevo. In third part I will use the agon category, which Roger Caillois used in his work about the games [Caillios, 1997], and which — based on This War of Mine — can be extended and redefined, taking into account the ambiguity of the term agon.

(C) Gieba, Kamila, 2019 
Before discussing these specific issues, it should be noted that war game is not a genre: this wording means rather a war-themed game that can be implemented in various genres: e.g. in strategies (Warhammer), role-playing games and actions (Call of Duty) or simulations (Silent Hunter). In the case of video games, the genre is not related to the theme, but to the category "characterized by a specific set of challenges, regardless of the scenery or content of the game world" [Adams, 2011: 110]. Depending on the specific genre, a set of rules governing the game world or goals will be shaped differently. Basically, however, war-related games have a specific story convention - a conflict between soldiers of hostile armies, accompanied by planning and taking tactical actions to lead to victory by reducing enemy forces. In This War of Mine, the player does not direct soldiers, but civilians, who do not have to deal with enemy troops, but more often with hunger, illness, coldness, and depression. The goal of the game is not to beat the opponent, but... just to survive.

\section{The plot and mechanics of This War of Mine}

The game randomly decides how many days the war lasts: usually thirty to forty five days. The game offers two main areas of activity closely related to time: shelter (day) and ruins of a besieged city (night). The entertainment mechanism may seem simple: during the day, the player-led heroes improve their shelter to help the group survive. At night, risking their lives, they go to the besieged city in search of building materials, food or medicine. The player manages a group of people who are initially strangers - they use a common shelter, but they did not know each other before the siege. Everyone, however, feels responsibility not only for themselves, but also for others. As a result, the game leads to the creation of a community for which the only chance to survive is acting for the benefit of the common good [Duda, 2012: 53]. Radosław Bomba states that the survival of the war in This War of Mine requires precisely the creation of a work-based community that benefits all members of the group: "It is also somewhat the idea of homeostasis, a balance based on specialization and symmetry of needs, which are to be a remedy for large and small conflicts" [Bomba, 2015: 92].

These small conflicts are quarrels within the group, which can lead to e.g. incompatibility of characters, but also frustration caused by starvation, sleep deprivation, and depression. However, any such conflict leads to negative consequences. Cooperation is the only chance to survive. Miłosz Piotrowiak, discussing This War of Mine, points out that the soldier's drill and tactical order of war operations do not reflect the chaos of civilian life in a besieged city: "The randomness of human fate, differences in character, mood swings lead to explosive moments and uncontrolled behavior, blur the plot transparency of the war adventures and multiply conflicts" [Piotrowiak, 2017: 57].

Bomba recognizes that the game is a life simulator and calls it "the Sims upside down" [Bomba, 2015]. This is a reference to the famous Electronic Art games, in which the player manages avatars, satisfying their basic needs, determined by such indicators as: "hunger", "sleep", "hygiene", "fun", "comfort", "energy", "companionship". In This War of Mine, the player must keep individuals alive, which is not easy in the world without food and water. When a person's condition worses, notifications informing about its condition are displayed: e.g. "hungy", "very hungry", "tired", "injured", "sick", "sad". It is worth emphasizing the importance of the latter, mental parameter: survival requires not only feeding the characters, but also maintaining them in the right mental condition. A sad character can become depressed - then the player can no longer control it. In extreme situations, when we lose control of a character, he may even commit 
suicide "by himself". The mood can worsen as a result of making a difficult moral choice, e.g. robbing a lonely old man to get food for the household. "Unlike typical war games, in which the player, as a commando, kills more enemies without any consequences, in This War of Mine, such behavior affects the character's condition" [Bomba, 2015: 93]. If one of the inhabitants dies, his death is felt by the others, who are in a state of mourning for some time, which in other warthemed games is rather unusual. The survivors have to work through the loss of a person who although initially completely stranger - in the face of common problems became close to them.

Unlike classic war action games, the challenges posed to the player in This War of Mine are also peculiar. In war "shooters", challenges are based primarily on speed and reaction time as well as accuracy and precision, necessary for, for example, firing an accurate shot. In the game discussed here, however, the player face conflict-based challenges and economic challenges [Adams, 2011: 326]. The primary goal of the conflict-related game is survival, which is the reverse of a game based on reducing your opponent's strength. The task in the area of economic challenges is to take care of living beings — this goal is related to economics, because achieving it requires proper organizing the means: food, water, medicines, as well as cigarettes and alcohol, which can temporarily improve the mood of the character or serve as a currency exchanged for food when trading with soldiers.

\section{Historical background}

The creators of the game admit that the inspiration for them was the war in the Balkans, and in particular the siege of Sarajevo. This is demonstrated by the trailer entitled The Survivor. In this short video, Emir Cerimovic talks about the siege of Sarajevo, which he survived as a little boy. His story is interspersed with scenes from This War of Mine. But in the game we do not come across clear indications of these inspirations (maybe except for the Slavic-sounding names of the characters, such as Pavle or Cveta). Paweł Miechowski, responsible for PR of the developer, directly points to the Balkan inspiration. He recalls the autobiographical tale One year in hell, whose author described the siege of Sarajevo:

For example, he described that when winter came, it was necessary to chop all the doors in the house to light the fireplace, or collect rainwater in the barrel, because the nearby river was contaminated by decaying corpses. You could only go out to the city at night, because during the day there was too much danger from the prowling bandits. The most terrible moments in the story were the times when you had to sacrifice something for the good of the group. The author of the article sums it all up with the statement that there are no "good ones" in the war - however hard you try, after all, with the need to survive, you will do something that you would never normally do, because remorse would consume you [Kozierkiewicz].

Miechowski further emphasizes that the creators' goal was not to provide the player with entertainment, but to bring to the fore the emotional and moral level. According to Piotrowiak, the game leads to ,bringing contemporary people to order, knocking them out of the comfort zone" [Piotrowiak, 2017: 59]. Although — as already mentioned — the game did not contain direct signals indicating the blockade of Sarajevo, the plot refers to the fate of the civilians of this city, whose siege lasted for three and a half years, from April 1992 to February 1996. In Barbara Demick's reportage Logavina Street. Life and Death in a Sarajevo Neighborhood, numerous 
statements of witnesses reporting the siege from the civilian perspective were cited. "This war took us not to the Middle Ages, but to the Stone Age" [Demick, 2014: 98] — said one of Demick's interlocutors, thus summarizing the story of survival in Sarajevo: the search for food, the construction of home stoves, life with minimal water resources, often without electricity and gas. "Here's what the war made of us [...]. We have become a nation of thieves" [Demick, 2014: 80] — confirms a resident of Sarajevo street Logavina.

This is also what the player faces This War of Mine - in order not to freeze, you need to build a stove; to protect against an attack, you need to patch up the walls of the shelter, to survive - you need to eat and drink (buying extremely expensive food on the basis of barter or stealing it from other civilians under the cover of night). The scenery of all these activities is the dramatic conflict that made civilians prisoners in their own city.

\section{Agon}

Roger Calliois, when classifying games, listed four types of gameplay, describing them with the terms: agon (competition or challenge), alea (randomness), mimicry (imitation) and ilinx (daze). In the context of this paper, it is not necessary to discuss all these categories. Instead, I wanted to pay attention primarily to agon. It is a competition-based conflict game in which gaining an advantage over an opponent consists in increasing your chances, which are equal for both sides at the beginning [Calliois, 1997: 23]. Here, the author of Games and people includes, among others, chess, checkers, sports competitions.

In This War of Mine we are certainly dealing with a conflict, but the opponent is not completely defined, and the chances are uneven - the characters the player directs are in a losing position throughout the game. There are also elements of randomness and uncertainty in the game, which is why, along with the agon, we should also mention alea - a game based on chance, such as dice, roulette and heads. The number of days after which the war ends is random; a random is the group of characters with whom we start the game; some locations are also random. According to Caillois, between these game paradigms - categories of conflict and randomness — there is a significant difference: "Agon refers to personal responsibility, agon is giving up the will, relying on the grace of fate" [Caillois, 1997: 26]. And further: "In agon the participant counts only on himself, [...] in alea he counts on everything else but himself, relying on powers over which he has no power" [Caillois, 1997: 48].

In This War of Mine both of these types come to the fore. Virtual characters are entangled in agon as the weaker - civil — side of the war conflict. At the same time, however, there is randomness in the game that results in unpredictability. As a result, the representation of war from a civilian perspective contains, on the one hand, a picture of intentional effort and taking planned actions to survive, on the other, an image of chaotic and unpredictable reality that is beyond the causative power of characters.

However, it is the agon category that turns out to be particularly productive for analyzing the gameplay offered by This War of Mine. This productivity, however, results not only from the findings made by Caillois. His suggestions can be extended based on the ambiguity of the term agon. It means, among others assembly, meeting place, fight and dispute. In ancient Greece, agon was defined as sports and dramatic games. In relation to these meanings, agon is conflict.

However, agon also means part of the Greek drama, and more precisely the dialogue between opponents - antagonists - in the course of which a dispute between them was outlined; agonist exchange of opinions could be aimed at resolving the disputed issue or convincing 
the opponent to their arguments [Cieśluk, 2008]. Agon in This War of Mine interacts with another meaning of the concept, also associated with dramatic structure. It means not only the clash of two opponents, but also the internal conflict taking place in the psyche of the person of the drama [Czerwińska, 2003].

Although the game analyzed here does not contain internal monologues, nevertheless the player manages the characters who must make decisions about the signs of a tragic conflict. It is the tragic conflict that sets the basic pattern of the story structure in This War of Mine. People under siege had to make difficult moral decisions, which often came down to choosing the lesser evil or simply... another evil.

Agon as a structural element of a dramatic text is part of a potential spectacle. A computer game is also a form of the spectacle: it is a fictionalized performance in which, among others, a key role is played visual aspect. Hyden White points out that visual codes in the story of the past are used rather as an addition to verbal codes. The researcher states: „In our historiographic culture we are more willing to use visual images as a supplement to written discourse than as a component of autonomous discourse, in which we could present other things and in a different way than in verbal form" [White, 2014: 257].

In the case of the game discussed here, the opposite is true. This War of Mine does not have an extensive text layer, instead of language significant elements are primarily visual representations of the besieged city and actions taken in this scenery. Also visually, This War of Mine differs from other war games, whose creators strive primarily for photorealism, trying to make the virtual world as real as possible. Meanwhile, this game is almost monochrome, poor in details, it presents only slices of the city, important because of the actions that the player can take in a given area. Therefore, the game offers a kind of interactive spectacle, the boundaries of which are set by the framework of possible actions limited to a civilian's incomplete perspective. Such landscape can - using a concept of Tim Ingold - be described as taskscape [Ingold, 2014: 147], which Łukasz Zaremba translates as "task image" [Zaremba, 2013: 4]. It is a space subordinate to the key tasks to be performed and as such becomes an area of efficiency - the conflict thus transforms into a mission performed in the space of the landscape determined by strategic places for survival.

\section{Conclusions}

After the end of the war — if the player has survived to this point — the game simply ends. Of course, it would be difficult to require the creators to produce a panoramic, interactive story about the long-term effects of life in the city after the siege ceased. Nevertheless, it is worth noting that we are dealing with a selective narrative - only what is important for the virtual spectacle is represented. There is also no information in the game about the complex background of the Balkan crisis, which was not only a fight for control of the territory, but also an ethnic war and religious conflict. Therefore, playing as a spectacle offers an incomplete, fragmentary picture of war, which, however, does not have to be an accusation, because virtual reality does not at all pretend to perform educational or cognitive functions.

In the summary, it is worth returning to the previously outlined feature of This War of Mine. Although the creators of the game cite the siege of Sarajevo as a source of inspiration, they do not signal it directly in the game itself. It can be assumed that this is a deliberate procedure. Depriving the location of characteristic elements that could indicate their relationship with real spaces and historical circumstances, makes the game become a universal story — it is not about 
a specific war, but about every war. After all, the war is not only on the front line or on the battlefield. As the motto accompanying This War of Mine says: "In war, not everyone is a soldier".

\section{References}

Adams, Ernest. Projektowanie gier. Podstawy [Fundamentals of Game Design]. Helion, 2011.

Bomba, Radosław. Simowie na wspak. Gra "This War of Mine" w perspektywie retoryki proceduralnej [,,The Sims" backwards "This War of Mine” in the perspective of procedural rhetoric]. Wielogtos 2015, no. 3.

Caillois, Roger. Gry i ludzie [Games and peoples]. Volumen, 1997.

Cieśluk, Małgorzata. Zagadki i agon mędrców w "Królu Edypie” Sofoklesa ["Oedipus the King” by Sophocles riddles and dual of sages]. Symbolae Philologorum Posnaniensium 2008, no. 18.

Czerwińska, Jadwiga. Agony racji w tragediach Eurypidesa: agon psychologiczny "Medei”[Agony of Reason in Euripides" Tragedies: The Psychological Agon of "Medea"]. Collectanea Philologica 2003, nr 5

Damick, Barbara. W oblężeniu. Życie pod ostrzałem na sarajewskiej ulicy [Logavina Street. Life and Death in a Sarajevo Neighborhood]. Czarne, 2014.

Duda, Maciej. Sarajewo jako metafora. Miasto i mit [Sarajevo as a metaphor. A city and a myth]. Białostockie Studia Literaturoznawcze 2012, no. 3.

Ingold, Tim. Czasowość krajobrazu [Temporality of the space], [in] B. Frydryczak, D. Angutek. Krajobrazy: antologia tekstów [Landscapes. Antology of texts], Poznań 2014.

Kozierkiewicz, Paweł. Widzieliśmy „, This War of Mine”, najbardziej wstrzasajaca grę tego roku [We saw ,, Tis War of Mine - the most shocking game of the year]. Online: https://antyweb.pl/widzielismy-this-war-of-mine-najbardziej-wstrzasajaca-gre-tego-roku/.

Piotrowiak, Miłosz. Nowe doświadczenie wojny. "This War of Mine” [A new war experience. "This War of Mine"]. Śląskie Studia Polonistyczne 2017, no. 1.

White, Hayden. Przeszłość praktyczna [The Practical Past]. Universitas, 2014.

Zaremba, Łukasz. Czy "wojny z terroryzmem” również nie było? [Was there no war on terror also?]. Widok. Teorie i Praktyki Kultury Wizualnej 2013, no. 2. 